\title{
ELECTROCHEMICAL REMOVAL OF BORON FROM WATER: ADSORPTION AND THERMODYNAMIC STUDIES
}

\author{
Subramanyan Vasudevan* and Jothinathan Lakshmi
}

CSIR, Central Electrochemical Research Institute, Karaikudi, Tamil Nadu, India

\begin{abstract}
The present work provides an electrochemical removal of boron from water and its kinetics, thermodynamics, isotherm using mild steel and stainless steel as anode and cathode respectively. The various operating parameters on the removal efficiency of boron were investigated, such as initial boron ion concentration, initial $\mathrm{pH}$, current density and temperature. The results showed that the optimum removal efficiency of $93.2 \%$ was achieved at a current density of $0.2 \mathrm{~A} \mathrm{dm}^{-2}$ at pH of 7.0. First-, second-order rate equations, Elovich and Intraparticle models were applied to study adsorption kinetics. Adsorption isotherms of boron on $\mathrm{Fe}(\mathrm{OH})_{3}$ were determined and correlated with isotherm equations such as Langmuir, Freundlich and D-R models. Thermodynamic parameters, such as standard Gibb's free energy $\left(\Delta C^{\circ}\right)$, standard enthalpy $\left(\Delta H^{\circ}\right)$ and standard entropy $\left(\Delta S^{\circ}\right)$, were also evaluated by Van't Hoff equation. The adsorption process follows second-order kinetics. The adsorption of boron preferably fits with Langmuir adsorption isotherm suggesting monolayer coverage of adsorbed molecules. The adsorption of boron onto $\mathrm{Fe}(\mathrm{OH})_{3}$ was found to be spontaneous and endothermic.
\end{abstract}

Keywords: boron removal, electrocoagulation, adsorption, isotherms, thermodynamics

\section{INTRODUCTION}

A wide variety of inorganic contaminants such as arsenic, chromium, cadmium, nitrate etc., can be found in surface, brackish and groundwater. Boron is another such contaminant of interest due to its occurrence in surface and groundwater. Boron is widely distributed in the environment as calcium and/or sodium borates, such as Colemanite, Ulexite and Tincal, etc. or from anthropogenic pollution mainly in the form of boric acid or borate salts. Boric acid and borate both exists as monomer in solution at low concentration (below $25 \mathrm{mM}$ ), but at higher concentration they appears as highly water soluble poly borate ions such as $\mathrm{B}_{3} \mathrm{O}_{3}(\mathrm{OH})_{4}^{-}, \mathrm{B}_{4} \mathrm{O}_{5}(\mathrm{OH})_{4}^{-}, \mathrm{B}_{5} \mathrm{O}_{6}(\mathrm{OH})_{4}^{-}$(Kistler and Helvac1, 1994; Peter, 1998; Senkal and Bicak, 2003; Yurdakoc et al., 2005; Bryjak et al., 2008). Borate deposits are rare, being found in dry regions of the world such as the USA, Turkey, Argentine, China, Russia and Chile. They are, however, extensively used by industry in the manufacture of glass wool, ceramics, borosilicate glass, flame retardants, detergents, wood preservatives, antifreeze, micro-nutrient fertilisers, etc. Since the use and the production of boron compounds are huge, the surface and ground water as well as sewage water contains elevated level of boron concentration (Sartaj and Fernandes, 2005; Baek et al., 2007; Bouguerra et al., 2008; Xu and Jiang, 2008). The recent European Union (EU) and USEPA drinking water directive defines an upper limit of $1 \mathrm{mg} \mathrm{B} / \mathrm{L}$. In order to consider the toxic effect of boron on humans, the EU and USEPA regulations are suggesting a guideline of $1.0 \mathrm{mg} \mathrm{L}^{-1}$ (Guidelines for Drinking-Water Quality, 1998; Jiang et al., 2007). In human, the sign of boron toxicity includes nausea, vomiting, diarrhea, dermatitis, decreased sexual activity, headache, skin rashes and central nervous system stimulation. Due to the toxicity of its compounds, create a pressing need for investigations aimed at developing effective methods to remove this element from aqueous solutions. Removing boron from water is difficult and can be prohibitively expensive and impractical (Bick and Ora, 2005; EnnilKose and Ozturk, 2008).

Conventional methods for removing boron include coagulation-precipitation, biological, ion exchange, membrane technology and electro-dialysis (Vik et al., 1984; Hazef et al., 2002; Inglezakis et al., 2003; Srivastava et al., 2006; Thella et al., 2008). Biological treatment methods cannot be used for boron removal from wastewaters, because inorganic boron compounds are antiseptics. Coagulation-precipitation methods are not effective and not feasible for boron removal. Ion exchange

\footnotetext{
* Author to whom correspondence may be addressed.

E-mail address: vasudevan65@gmail.com

Can. J. Chem. Eng. 90:1017-1026, 2012

(C) 2011 Canadian Society for Chemical Engineering DOI $10.1002 /$ cjce. 20585

Published online 21 June 2011 in Wiley Online Library (wileyonlinelibrary.com).
} 
processes by resin, which is expensive as a consequence of regeneration. In general, conventional processes have considerable disadvantages including incomplete metal removal, requirements for expensive equipment and monitoring system, high reagent and energy requirements or generation of toxic sludge or other waste products that require disposal (Sahin, 2003).

During the last few decades, electrochemical water treatment technologies have undergone rapid growth and development. One of these technologies is the electrochemically assisted coagulation that can compete with the conventional chemical coagulation process. Electrochemically generated metallic ions from these electrodes undergo hydrolysis near the anode to produce a series of activated intermediates that are able to destabilise the finely dispersed particles present in the water and waste water to be treated. The advantages of electro coagulation include high particulate removal efficiency, a compact treatment facility, relatively low cost and the possibility of complete automation (Chen et al., 2002; Chen, 2004; Ali and Gupta, 2007; Gupta et al., 2007, 2009; Yilmaz et al., 2007, 2008; Vasudevan et al., 2009a,b,c, 2010). Usually, iron or aluminium plates are used as electrodes in the electro coagulation followed by electro sorption process.

(i) When iron is used as the electrode, the reactions are as follows:

At the cathode:

$2 \mathrm{H}_{2} \mathrm{O}+2 \mathrm{e}^{-} \rightarrow \mathrm{H}_{2}(\mathrm{~g})+2 \mathrm{OH}^{-}$

At the anode:

$4 \mathrm{Fe} \rightarrow 4 \mathrm{Fe}^{2+}+8 \mathrm{e}^{-}$

In the solution:

$4 \mathrm{Fe}(\mathrm{aq})+10 \mathrm{H}_{2} \mathrm{O}+\mathrm{O}_{2} \rightarrow 4 \mathrm{Fe}(\mathrm{OH})_{3}+10 \mathrm{H}_{2}$

(ii) When aluminum is used as electrode, the reactions are as follows:

At the cathode:

$2 \mathrm{H}_{2} \mathrm{O}+2 \mathrm{e}^{-} \rightarrow \mathrm{H}_{2}(\mathrm{~g})+2 \mathrm{OH}^{-}$

At the anode:

$\mathrm{Al} \rightarrow \mathrm{Al}^{3+}+3 \mathrm{e}^{-}$

In the solution:

$\mathrm{Al}^{3+}(\mathrm{aq})+3 \mathrm{H}_{2} \mathrm{O} \rightarrow \mathrm{Al}(\mathrm{OH})_{3}(\mathrm{~s})+3 \mathrm{H}^{+}$

Although, there are numerous reports related to electrochemically assisted coagulation as a means of removal of many pollutants from water and wastewater using aluminum as anode material, but there are limited work on boron removal by electrochemically assisted method using mild steel as anode material and its adsorption and kinetics studies. The main disadvantage in case of aluminum electrode is the residual aluminum (The USEPA guidelines suggest maximum contamination is $0.05-0.2 \mathrm{mg} \mathrm{L}^{-1}$ ) present in the treated water due to well-known cathodic dissolution. This will create health problems like cancer. In the case of mild steel electrodes, there is no such disadvantage like aluminum electrodes.
This work presents the results of the laboratory scale as well as scale-up studies on the removal of boron using mild steel and stainless steel as anode and cathode respectively. To optimise the maximum removal efficiency of boron, different parameters like effect of current density, initial boron concentration, temperature, $\mathrm{pH}$ and effect of co-existing ions like carbonate, phosphate, silicate and arsenic were studied. The adsorption kinetics of electrocoagulants are analysed by using first and second order kinetic, Elovich and Intraparticle models. The equilibrium adsorption models of Langmuir, Freundlich and Dubinin-Radushkevich were also studied and the activation energy is calculated to study the nature of the adsorption.

\section{EXPERIMENTAL SECTION}

\section{Cell Construction and Electrolysis}

Figure 1 shows the electrolytic cell consisting of a 1.0-L Plexiglas vessel that was fitted with a polycarbonate cell cover with slots to introduce the anode, cathode, $\mathrm{pH}$ sensor, a thermometer and electrolytes. The anode and cathode, commercial grade, with surface area of $0.2 \mathrm{dm}^{2}$ were made of mild steel and stainless steel respectively are placed at an inter-electrode distance of $0.005 \mathrm{~m}$. The temperature of the electrolyte has been controlled to the desired value with a variation of $\pm 2 \mathrm{~K}$ by adjusting the rate of flow of thermostatically controlled water through an external glass-cooling spiral. A regulated direct current (DC) was supplied from a rectifier ( $50 \mathrm{~A}, 0-25 \mathrm{~V}$; Aplab model).

The boron as boric acid $\left(\mathrm{H}_{3} \mathrm{BO}_{4}\right)$ (Analar Reagent; Merck, Darmstadt, Germany) was dissolved in distilled water for the required concentration $\left(3-7 \mathrm{mg} \mathrm{L}^{-1}\right)$. The solution of $0.90 \mathrm{~L}$ was used for each experiment as the electrolyte. The $\mathrm{pH}$ of the electrolyte was adjusted, if required, with $1 \mathrm{M} \mathrm{HCl}$ or $1 \mathrm{M} \mathrm{NaOH}$ (AR Grade; Merck) solutions before start of the experiments. To study the effect of co-existing ions, in the removal of boron, sodium salts (Analar Grade; Merck) of phosphate $\left(0-50 \mathrm{mg} \mathrm{L}^{-1}\right)$, silicate $\left(0-15 \mathrm{mg} \mathrm{L}^{-1}\right)$, carbonate $\left(0-250 \mathrm{mg} \mathrm{L}^{-1}\right)$ and arsenic (0-5.0 $\left.\mathrm{mg} \mathrm{L}^{-1}\right)$ was added to the electrolyte.

\section{Analytical Procedure}

The boron was analysed using UV-Visible Spectrophotometer (Merck, Spectroquant Pharo 300). The SEM and EDAX of

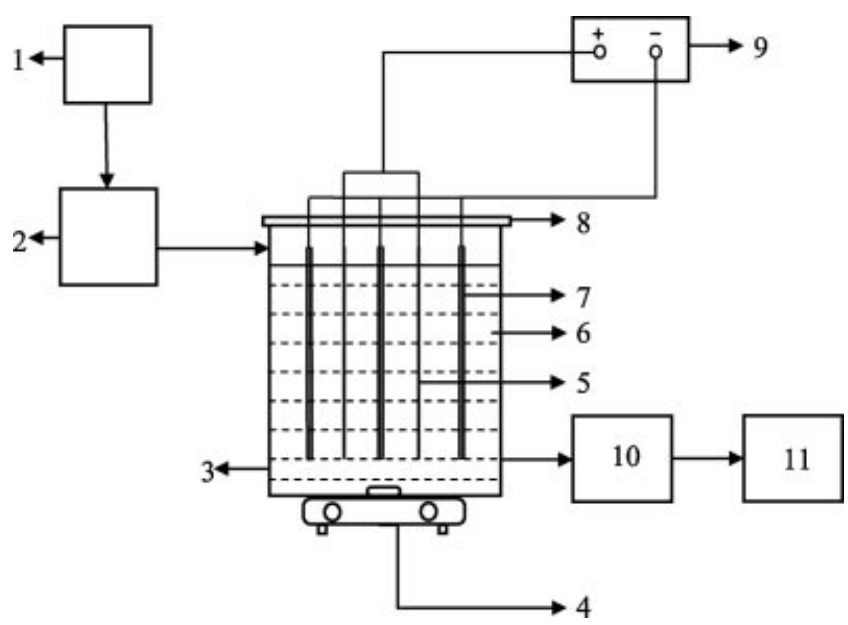

Figure 1. Laboratory scale cell assembly. 1. pH Sensor, 2. Water tank, 3. Electrolytic cell, 4. Magnetic Stirrer, 5. Anode, 6. Electrolyte, 7. Cathode, 8. PVC cover, 9. Power supply, 10. Filter, 11. Treated water tank. 
boron-adsorbed ferric hydroxide coagulant were analysed with a SEM made by Hitachi (model s-3000 h). The Fourier transform infrared spectrum of ferric hydroxide was obtained using Nexus 670 FTIR spectrometer (Thermo Electron Corporation, Barrington). The concentration of carbonate, silicate, arsenic and phosphate were determined using UV-Visible Spectrophotometer (Merck, Pharo 300).

\section{RESULTS AND DISCUSSION}

\section{Effect of Amount of Coagulant}

The amount of boron removal depends upon the quantity of adsorbent (ferric hydroxide) generated, which is related to the time and current density. The amount of adsorbent $\left[\mathrm{Fe}(\mathrm{OH})_{3}\right]$ was determined from the Faraday law (Golder et al., 2006):

$E_{\mathrm{c}}=\frac{I t M}{Z F}$

where $I$ is current in A, $t$ is the time (s), $M$ is the molecular weight, $Z$ is the electron involved and $F$ is the Faraday constant ( 96485.3 coulomb mole ${ }^{-1}$ ). With the increase in current density the amount of ferric hydroxide also increases. To investigate the effect of current density on the boron removal, a series of experiments were carried out by solutions containing a constant pollutants loading of $5 \mathrm{mg} \mathrm{L}^{-1}$, at a $\mathrm{pH} 7.0$, with current density being varied from 0.1 to $0.5 \mathrm{~A} \mathrm{dm}^{-2}$. The removal efficiency was found to be $74.1 \%, 93.2 \%, 94.1 \%, 94.8 \%$ and $95.0 \%$ for the current densities varying from $0.1,0.2,0.3,0.4$ and $0.5 \mathrm{~A} \mathrm{dm}^{-2}$ showing the amount of boron adsorption increases with the increase in adsorbent concentration, which indicates that the adsorption depends up on the availability of binding sites for boron. It is found that, above $0.2 \mathrm{~A} \mathrm{dm}^{-2}$ the removal efficiency remains almost constant for higher current densities. So, all further studies were carried out at $0.2 \mathrm{~A} \mathrm{dm}^{-2}$.

\section{Effect of Electrolyte $\mathrm{pH}$}

The $\mathrm{pH}$ is one of the important factors affecting the performance of electrochemical process. To examine this effect, a series of experiments were carried out using $5 \mathrm{mg} \mathrm{L}^{-1}$ boron containing solutions, with an initial $\mathrm{pH}$ varying in the range $2-12$ at a current density of $0.2 \mathrm{~A} \mathrm{dm}^{-2}$. From the results it is found that boron removal efficiency increased with the $\mathrm{pH}$ up to 7.0 and then decreased. The maximum removal efficiency for the removal of boron is $93.2 \%$ at pH 7 and the minimum efficiency is $64.1 \%$ at pH 12 . At acidic and alkaline $\mathrm{pH}$, the oxide surfaces exhibit net positive and negative charges respectively and would tend to repulse the adsorption of boron and resulting the maximum adsorption at $\mathrm{pH} 7$. The highest boron removal efficiency was obtained at $\mathrm{pH} 7.0$ because boron was at $\mathrm{B}(\mathrm{OH})_{3}$ form and the formation $\mathrm{Fe}(\mathrm{OH})_{3}$ was a quite high at this $\mathrm{pH}$.

\section{Effect of Initial Boron Concentration}

In order to evaluate the effect of initial boron concentration, experiments were conducted at varying initial concentration of boron from 3 to $7 \mathrm{mg} \mathrm{L}^{-1}$. Figure 2 shows that the uptake of boron $\left(\mathrm{mgg}^{-1}\right)$ increased with increase in boron concentration and remained nearly constant after equilibrium time. The equilibrium time was found to be $60 \mathrm{~min}$ for all concentration studied. After $60 \mathrm{~min}$, the amount of boron adsorbed $\left(q_{\mathrm{e}}\right)$ increased from 1.9966 to $5.5103 \mathrm{mg} \mathrm{g}^{-1}$ as the concentration increased from $3-7 \mathrm{mg} \mathrm{L}^{-1}$. The figure also shows that the adsorption is the rapid in the ini-

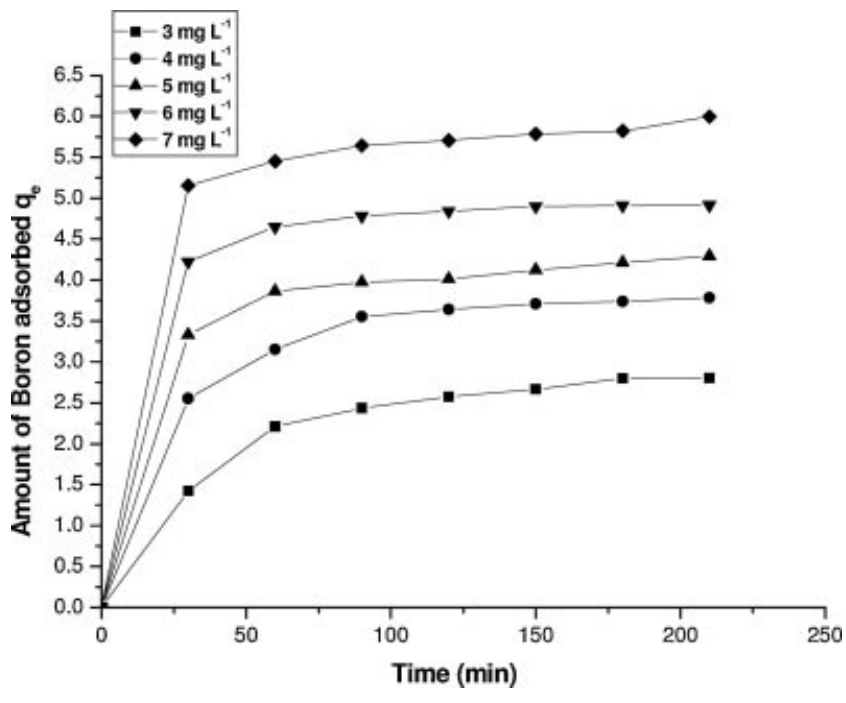

Figure 2. Effect of reaction time and amount of boron adsorbed at different concentrations.

tial stages and remains almost constant with the progress of the adsorption. The plots are single, smooth and continuous curves leading to saturation, suggesting the possible monolayer coverage to boron on the surface of the adsorbent (Namasivayam and Prathap, 1999).

\section{Effect of Coexisting lons}

\section{Carbonate}

Effect of carbonate on boron removal was evaluated by increasing the carbonate concentration from 2 to $250 \mathrm{mg} \mathrm{L}^{-1}$ in the electrolyte. The removal efficiencies are $93.2 \%, 90.4 \%, 46.2 \%$, $44.1 \%, 21.0 \%$ and $10.0 \%$ for the carbonate ion concentration of $0,2,5,65,150$ and $250 \mathrm{mg} \mathrm{L}^{-1}$ respectively. From the results it is found that the removal efficiency of the boron is not affected by the presence of carbonate below $2 \mathrm{mg} \mathrm{L}^{-1}$. Significant reduction in removal efficiency was observed above $5 \mathrm{mg} \mathrm{L}^{-1}$ of carbonate concentration is due to the passivation of anode resulting, the hindering of the dissolution process of anode (Kabay et al., 2008).

\section{Phosphate}

The concentration of phosphate ion was increased from 2 to $50 \mathrm{mg} \mathrm{L}^{-1}$, the contaminant range of phosphate in the ground water. The removal efficiency for boron was $93.2 \%, 87.6 \%$, $60.2 \%, 51 \%$ and $38 \%$ for $0,2,5,25$ and $50 \mathrm{mg} \mathrm{L}^{-1}$ of phosphate ion respectively. There is no change in removal efficiency of boron below $2 \mathrm{mg} \mathrm{L}^{-1}$ of phosphate in the water. At higher concentrations (at and above $5 \mathrm{mg} \mathrm{L}^{-1}$ ) of phosphate, the removal efficiency decreases drastically. This is due to the preferential adsorption of phosphate over boron as the concentration of phosphate increase.

\section{Arsenic}

From the results it is found that the removal efficiency of boron decreased from $93.2 \%, 83 \%, 72.8 \%, 70.4 \%$ and $65 \%$ by increasing the concentration of arsenate from $0,0.2,0.5,2$ and $5 \mathrm{mg} \mathrm{L}^{-1}$. Like phosphate ion, this is due to the preferential adsorption of arsenic over boron as the concentration of arsenate increases. So, when arsenic ions are present in the water to be treated arsenic ions compete greatly with boron ions for the binding sites. 


\section{Silicate}

The removal efficiencies of boron following silicate additions of $0,2,5,10$ and $15 \mathrm{mg} \mathrm{L}^{-1}$ are $93.2 \%, 85.3 \%, 67.5 \%, 59.0 \%$ and $36.0 \%$. The removal of boron decreased with increasing silicate concentration from 2 to $15 \mathrm{mg} \mathrm{L}^{-1}$. In addition to preferential adsorption, silicate can interact with ferric hydroxide to form soluble and highly dispersed colloids that are not removed by normal filtration.

\section{Studies on Adsorption Kinetics}

In order to establish kinetic of boron adsorption, adsorption kinetics of mild steel was investigated by using first order, second order kinetic models, Elovich and Intraparticle diffusion.

\section{First and Second Order Lagergren Model}

The first order Lagergren model is generally expressed as follows (Singh et al., 2005):

$\frac{\mathrm{d} q_{\mathrm{t}}}{\mathrm{d} t}=k_{1}\left(q_{\mathrm{e}}-q_{t}\right)$

where $q_{\mathrm{e}}$ and $q_{t}$ are the adsorption capacities at equilibrium and at time $t(\mathrm{~min})$ respectively, and $k_{1}\left(\mathrm{~min}^{-1}\right)$ is a rate constant. Equation (8) can be linearised for use in the kinetic analysis of experimental analysis by applying boundary conditions $t=0$ to $t=t$ and $q_{t}=0$ to $q_{t}=q_{t}$ as follows:

$\log \left(q_{\mathrm{e}}-q_{t}\right)=\log \left(q_{\mathrm{e}}\right)-\left(\frac{k_{1} t}{2.303}\right)$

The values of $\log \left(q_{\mathrm{e}}-q_{t}\right)$ were linearly correlated with $\mathrm{t}$. The plot of $\log \left(q_{\mathrm{e}}-q_{t}\right)$ versus $t$ should give the linear relationship from which $k_{1}$ and $q_{\mathrm{e}}$ can be determined by the slope and intercept of the respectively (figure not shown).

The Lagregren second order kinetic model is expressed as (Mckay and Ho, 1999):

$\frac{\mathrm{d} q_{t}}{\mathrm{~d} t}=k_{2}\left(q_{\mathrm{e}}-q_{t}\right)^{2}$

where $k_{2}$ is the rate constant of second order adsorption. The integrated form of Equation (10) with the boundary condition $t=0$ to $t>0(q=0$ to $q>0)$ is:

$\frac{1}{\left(q_{\mathrm{e}}-q_{t}\right)}=\left(\frac{1}{q_{\mathrm{e}}}\right)+k_{2} t$

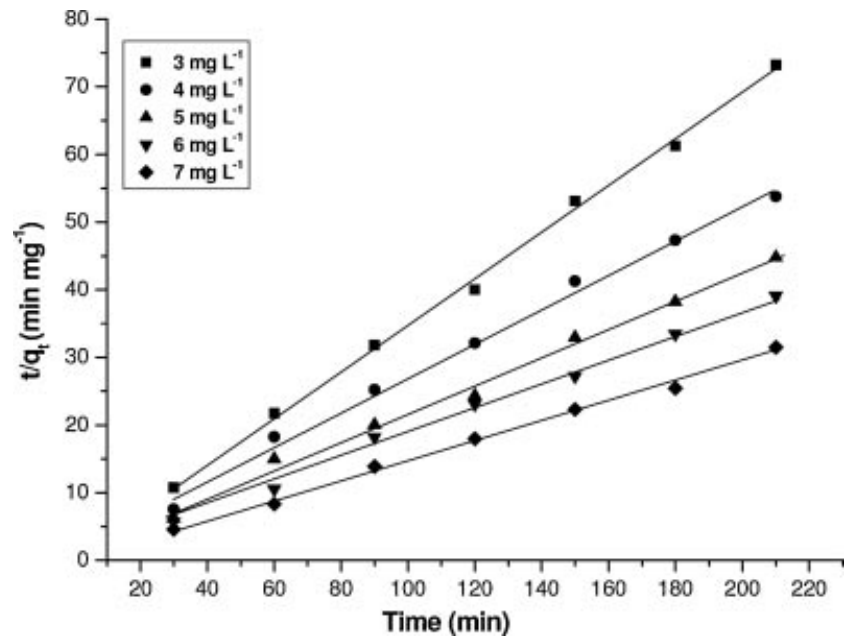

Figure 3. Second order kinetic model plot of different concentrations of boron.

Equation (11) can be rearranged and linearised as:

$\left(\frac{t}{q_{t}}\right)=\left(\frac{1}{k_{2} q_{\mathrm{e}}^{2}}\right)+\left(\frac{t}{q_{\mathrm{e}}}\right)$

The plot of $t / q_{t}$ and time ( $t$ ) (Figure 3) gave a linear relationship from which $q_{\mathrm{e}}$ and $k_{2}$ can be determined from the slope and intercept of the plot with high regression co-efficient. Table 1 shows the computed results of first and second order kinetics. The calculated $q_{\mathrm{e}}$ values well agree with experimental $q_{\mathrm{e}}$ values with high regression value for second order kinetic model.

\section{Elovich Equation}

The Elovich model equation is generally expressed as (Oke et al., 2008):

$\frac{\mathrm{d} q_{t}}{\mathrm{~d} t}=\alpha \exp \left(-\beta q_{t}\right)$

the simplified form of Elovich Equation (13) is:

$q_{t}=\left(\frac{1}{\beta \log _{\mathrm{e}}(\alpha \beta)}\right)+\left(\frac{1}{\beta \log _{e}(t)}\right)$

where $\alpha$ is the initial adsorption rate $\left(\mathrm{mgg}^{-1} \mathrm{~h}^{-1}\right)$ and, $\beta$ is the desorption constant $\left(\mathrm{g} \mathrm{mg}^{-1}\right)$. If boron adsorption fits the Elovich model, a plot of $q_{t}$ versus $\log _{\mathrm{e}}(t)$ should yield a linear relationship with the slope of $(1 / \beta)$ and an intercept of $1 / \beta \log _{\mathrm{e}}(\alpha \beta)$. Table 2 depicts the results obtained from Elovich equation. Lower regression value shows the inapplicability of this model.

Table 1. Comparison between the experimental and calculated $q_{\mathrm{e}}$ values for different initial boron concentration in first order and second order adsorption kinetics at room temperature

\begin{tabular}{|c|c|c|c|c|c|c|c|}
\hline \multirow[b]{2}{*}{ Concentration $\left(\mathrm{mg} \mathrm{L}^{-1}\right)$} & \multirow[b]{2}{*}{$q_{\mathrm{e}}(\exp )$} & \multicolumn{3}{|c|}{ First order adsorption } & \multicolumn{3}{|c|}{ Second order adsorption } \\
\hline & & $q_{\mathrm{e}}(\mathrm{Cal})$ & $K_{1} \times 10^{4}\left(\mathrm{~min} \mathrm{mg}^{-1}\right)$ & $R^{2}$ & $q_{\mathrm{e}}(\mathrm{Cal})$ & $K_{2} \times 10^{4}\left(\min \mathrm{mg}^{-1}\right)$ & $R^{2}$ \\
\hline 3 & 1.9966 & 24.31 & -0.0066 & 0.8122 & 2.1642 & 0.0335 & 0.9992 \\
\hline 4 & 2.9121 & 26.33 & -0.0071 & 0.8176 & 3.0115 & 0.0568 & 0.9956 \\
\hline 5 & 3.8664 & 28.31 & -0.0083 & 0.8431 & 3.9132 & 0.0633 & 0.9965 \\
\hline 6 & 4.6822 & 29.32 & -0.0091 & 0.8314 & 4.9132 & 0.0701 & 0.9942 \\
\hline 7 & 5.5103 & 30.94 & -0.0098 & 0.8846 & 5.6311 & 0.0766 & 0.9999 \\
\hline
\end{tabular}


Table 2. Elovich model and intra particle diffusion for different initial boron concentrations at temperature $305 \mathrm{~K}$ and $\mathrm{pH} 7$

\begin{tabular}{|c|c|c|c|c|c|}
\hline \multicolumn{3}{|c|}{ Elovich model } & \multicolumn{3}{|c|}{ Intra particle diffusion } \\
\hline$A\left(\mathrm{mg} \mathrm{g}^{-1} \mathrm{~h}^{-1}\right)$ & $\beta\left(\mathrm{g} \mathrm{mg}^{-1}\right)$ & $R^{2}$ & $k_{\text {id }}\left(\mathrm{Ih}^{-1}\right)$ & $A\left(\% \mathrm{~h}^{-1}\right)$ & $R^{2}$ \\
\hline 12.21 & 53.11 & 0.8012 & 31.25 & 0.181 & 0.7658 \\
\hline 6.34 & 36.32 & 0.7344 & 30.33 & 0.194 & 0.7134 \\
\hline 2.01 & 24.64 & 0.8011 & 29.21 & 0.201 & 0.6645 \\
\hline 1.99 & 20.14 & 0.8132 & 28.34 & 0.221 & 0.7132 \\
\hline 0.96 & 15.31 & 0.8312 & 26.33 & 0.294 & 0.7674 \\
\hline
\end{tabular}

\section{Intra-particle Diffusion}

The intraparticle diffusion model is expressed (Weber and Morris, 1963; Allen et al., 1989):

$R=k_{\mathrm{id}}(t)^{\alpha \mathrm{z}}$

A linearised form the Equation (15) is followed by:

$\log R=\log k_{\mathrm{id}}+a \log (t)$

in which ' $a$ ' depicts the adsorption mechanism and $k_{\text {id }}$ may be taken as the rate factor (percent of boron adsorbed per unit time). Lower and higher value of $k_{\text {id }}$ illustrates an enhancement in the rate of adsorption and better adsorption with improved bonding between pollutant and the adsorbent particles respectively. The results are presented in Table 2 .

Tables 1 and 2 depicts the computed results obtained from first order, second order, Elovich and intraparticle diffusion. From tables, it is found that the correlation coefficient decreases from second order, first order, intraparticle diffusion to Elovich model. This indicates that the adsorption follows the second order than the other models. Further, the calculated $q_{\mathrm{e}}$ values agree much better with the experimental $q_{\mathrm{e}}$ values for second order kinetics model, thus indicating that the adsorption system follows the second order kinetics model.

\section{Studies on Adsorption Isotherm}

To investigate the adsorption capacity of boron on $\mathrm{Fe}(\mathrm{OH})_{3}$ Freundlich, Langmuir and Dubinin-Radushkevich isotherms were analysed. These models have been widely used to describe the behaviour of adsorbent-adsorbate systems. To obtain the isotherms the initial $\mathrm{pH}$ was kept at 7 and the concentration of boron used was in the range of $3-7 \mathrm{mg} \mathrm{L}^{-1}$.

\section{Freundlich Isotherm}

According to the Freundlich isotherm model, the amount of adsorbed compounds initially increased rapidly and as the surface coverage increased the trend decreased. The linearised in logarithmic form and the Freundlich constants can be expressed as (Gasser et al., 2007; Uber, 1906):

$\log q_{\mathrm{e}}=\log k_{\mathrm{f}}+n \log C_{\mathrm{e}}$

where, $k_{\mathrm{f}}$ is the Freundlich constant related to adsorption capacity, $n$ is the energy or intensity of adsorption, $C_{\mathrm{e}}$ is the equilibrium concentration of boron $\left(\mathrm{mg} \mathrm{L}^{-1}\right)$. In testing the isotherm, the boron concentration used was $3-7 \mathrm{mg} \mathrm{L}^{-1}$ and at an initial $\mathrm{pH}$ 7 , the adsorption data is plotted as $\log q_{\mathrm{e}}$ versus $\log C_{\mathrm{e}}$ and should result in a straight line with slope $\mathrm{n}$ and intercept $k_{\mathrm{f}}$. The intercept and the slope are indicators of adsorption capacity and adsorption intensity respectively. The value of ' $n$ ' falling in the range of 1-10 indicates favourable sorption. The Freundlich constants $k_{\mathrm{f}}$ and $n$ values are $0.4624\left(\mathrm{mgg}^{-1}\right)$ and $0.9794\left(\mathrm{~L} \mathrm{mg}^{-1}\right)$ respectively. It has been reported that values of ' $n$ ' lying between 0 and 10 indicate favourable adsorption. From the analysis of the results it is found that the Freundlich plots fit satisfactorily with the experimental data obtained in the present study. This is agreed with the results presented in the literature (Giles et al., 1960).

\section{Langmuir Isotherm}

An alternative equation was derived by Langmuir on the basis of a definite case of the nature of the process of adsorption from solution. The maximum adsorption occurs when molecules adsorbed on the surface of the adsorbent form a saturated layer. The linearised form of Langmuir adsorption isotherm model is (Langmuir, 1918):

$\frac{C_{\mathrm{e}}}{q_{\mathrm{e}}}=\left(\frac{1}{q_{\mathrm{m}} k_{\mathrm{a}}}\right)+\left(\frac{C_{\mathrm{e}}}{q_{\mathrm{m}}}\right)$

where $C_{\mathrm{e}}$ is the concentration of the boron solution $\left(\mathrm{mg} \mathrm{L}^{-1}\right)$ at equilibrium, $q_{\mathrm{m}}$ is the adsorption capacity (Langmuir constant) and $k_{\mathrm{a}}$ is the energy of adsorption. Figure 4 shows the Langmuir plot with experimental data. Langmuir plot is a better fit with the experimental data compare to Freundlich plots. The value of the adsorption capacity $q_{\mathrm{m}}$ as found to be $104.33 \mathrm{mg} \mathrm{g}^{-1}$. The essential characteristics of the Langmuir isotherm can be expressed as the dimensionless constant $R_{\mathrm{L}}$ (Michelson et al., 1975):

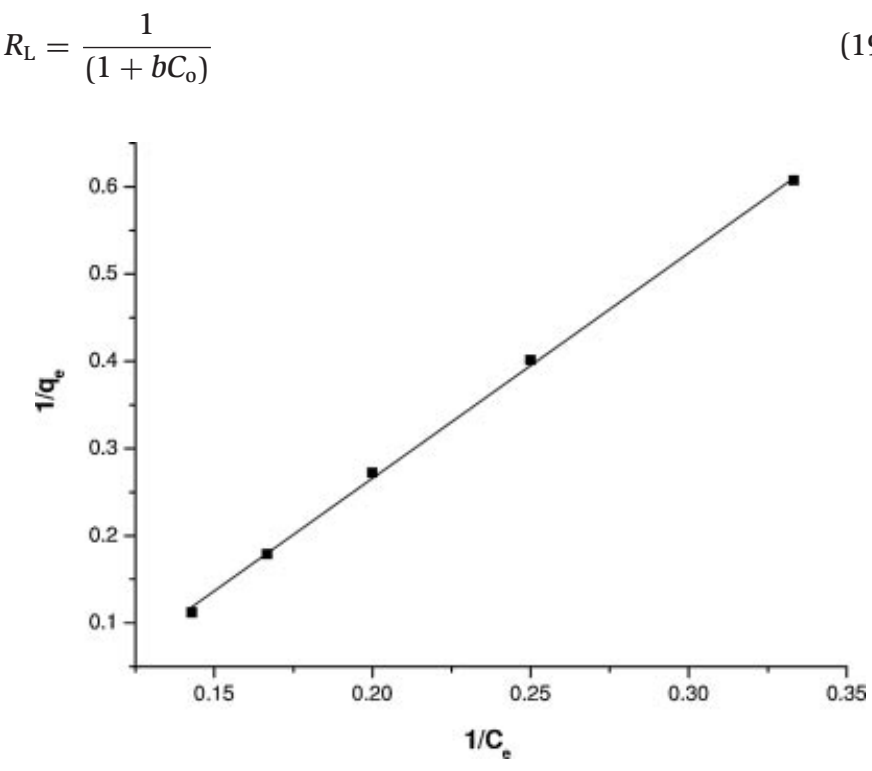

Figure 4. Langmuir plot $\left(1 / q_{\mathrm{e}}\right.$ vs. $\left.1 / C_{\mathrm{e}}\right)$ at $305 \mathrm{~K}$. 
Table 3. Constant parameters and correlation coefficient for different adsorption isotherm models for boron adsorption at $5 \mathrm{mg} \mathrm{L}^{-1}$

Isotherm

Constants

\begin{tabular}{|c|c|c|c|c|}
\hline \multirow[t]{2}{*}{ Langmuir } & $q_{\mathrm{m}}\left(\mathrm{mg} \mathrm{g}^{-1}\right)$ & $k_{\mathrm{a}}\left(\mathrm{L} \mathrm{mg}^{-1}\right)$ & $R_{\mathrm{L}}$ & $R^{2}$ \\
\hline & 104.33 & 0.0033 & 0.9091 & 0.9999 \\
\hline \multirow[t]{2}{*}{ Freundlich } & $k_{\mathrm{f}}\left(\mathrm{mg} \mathrm{g}^{-1}\right)$ & $n\left(\mathrm{~L} \mathrm{mg}^{-1}\right)$ & & $R^{2}$ \\
\hline & 0.4624 & 0.9794 & & 0.9845 \\
\hline & 0.9463 & 0.6651 & 14.62 & 0.8656 \\
\hline
\end{tabular}

where $R_{\mathrm{L}}$ is the equilibrium constant it indicates the type of adsorption, $b$, is the Langmuir constant. $C_{0}$ is various concentration of boron solution. The $R_{\mathrm{L}}$ values between 0 and 1 indicate the favourable adsorption. The $R_{\mathrm{L}}$ values were found to be between 0 and 1 for all the concentration of boron studied.

\section{Dubinin-Radushkevich Isotherm}

Dubinin-Radushkevich isotherm assumes that characteristic sorption curve is related to the porous structure of the sorbent and apparent energy of adsorption. This model is given by:

$q_{\mathrm{e}}=q_{\mathrm{s}} \exp \left(-B e^{2}\right)$

where $\varepsilon$ is polanyi potential, equal to $\mathrm{RT} \ln \left(1+1 / C_{\mathrm{e}}\right), B$ is related to the free energy of sorption and $q_{\mathrm{s}}$ is the Dubinin-Radushkevich (D-R) isotherm constant (Tan et al., 2007). The linearised form is:

$\ln q_{\mathrm{e}}=\ln q_{\mathrm{s}}-2 B \mathrm{RT} \ln \left[1+\left(\frac{1}{C_{\mathrm{e}}}\right)\right]$

The isotherm constants of $q_{\mathrm{s}}$ and $B$ are obtained from the intercept and slope of the plot of $\ln q_{\mathrm{e}}$ versus $\varepsilon^{2}$ (Demiral et al., 2008) The constant $\mathrm{B}$ gives the mean free energy of adsorption per molecule of the adsorbate when it is transferred from the solid from infinity in the solution and the relation is given as:

$E=\left(\frac{1}{\sqrt{2 B}}\right)$

The magnitude of $E$ (activation energy) is useful for estimating the type of adsorption process. It was found to be $14.62 \mathrm{~kJ} \mathrm{~mol}^{-1}$, is placed between the energy ranges of adsorption reaction (8-16 kJ mol-1), (Oguz, 2005). So the type of adsorption of boron on ferric hydroxide was defined as chemical adsorption.

The correlation co-efficient values of different isotherm models are listed in Table 3. The Langmuir isotherm model has higher regression co-efficient $\left(R^{2}=0.999\right)$ when compared to the other models. The value of $R_{\mathrm{L}}$ for the Langmuir isotherm was calculated between 0 and 1, indicating the favourable adsorption of boron.

\section{Thermodynamic Studies}

To understand the effect of temperature on the adsorption process, thermodynamic parameters should be determined at various temperatures. The amount of boron adsorbed on the adsorbent increases by increasing the temperature indicating the process to be endothermic. The energy of activation for adsorption of boron can be determined by the second order rate constant is expressed in Arrhenius form:

$\ln k_{2}=\ln k_{\mathrm{o}}-\left(\frac{E}{R T}\right)$

where $k_{0}$ is the constant of the equation $\left(\mathrm{g} \mathrm{mg}^{-1} \mathrm{~min}^{-1}\right), E$ is the energy of activation $\left(\mathrm{J} \mathrm{mol}^{-1}\right), R$ is the gas constant (8.314 $\mathrm{J} \mathrm{mol}^{-1} \mathrm{~K}^{-1}$ ) and $T$ is the temperature in $\mathrm{K}$. Figure 5 shows that the rate constants vary with temperature according to Equation (23). The activation energy $\left(0.7382 \mathrm{~kJ} \mathrm{~mol}^{-1}\right)$ is calculated from slope of the fitted equation. The free energy change is obtained using the following relationship,

$\Delta G=-R T \ln K_{\mathrm{c}}$

where ( $G$ is the free energy $\left(\mathrm{kJ} \mathrm{mol}^{-1}\right), K_{\mathrm{c}}$ is the equilibrium constant, $R$ is the gas constant and T is the temperature in $K$. The $K_{\mathrm{c}}$ and $(G$ values are presented in Table 4 . From the table it is found that the negative value of ( $G$ indicates the spontaneous nature of adsorption. Other thermodynamic parameters such as entropy change $(\Delta S)$ and enthalpy change $(\Delta H)$ were determined using van't Hoff equation:

$\ln K_{\mathrm{c}}=\frac{\Delta S}{R}-\frac{\Delta H}{R T}$

The enthalpy change $\left(\Delta H=7.892 \mathrm{~J} \mathrm{~mol}^{-1}\right)$ and entropy change ( $\Delta S=9.441 \mathrm{~J} \mathrm{~mol}^{-1} \mathrm{~K}^{-1}$ ) were obtained from the slope and intercept of the van't Hoff linear plots of $\operatorname{lnk}_{\mathrm{c}}$ versus $1 / T$ (Figure 6). Positive value of enthalpy change $(\Delta H)$ indicates that the adsorption process is endothermic in nature, and the negative value of change in internal energy $(\Delta G)$ show the spontaneous adsorption of boron on the adsorbent. Positive values of entropy change show the increased randomness of the solution interface during the adsorption of boron on the adsorbent (Table 4). Enhancement

Table 4. Thermodynamics parameters for adsorption of boron

\begin{tabular}{lccc}
\hline Temperature $(\mathrm{K})$ & $K_{\mathrm{c}}$ & $\left(\mathrm{G}^{\circ}\left(\mathrm{J} \mathrm{mol}^{-1}\right)\right.$ & $\left(\mathrm{H}^{\circ}(\mathrm{kJ} \mathrm{mol})^{-1}\right)$ \\
\hline 313 & 1.0096 & -111.33 & 7.892 \\
323 & 1.1164 & -204.66 & \\
333 & 1.3226 & -316.42 & \\
343 & 1.3966 & -447.33 & \\
\hline
\end{tabular}




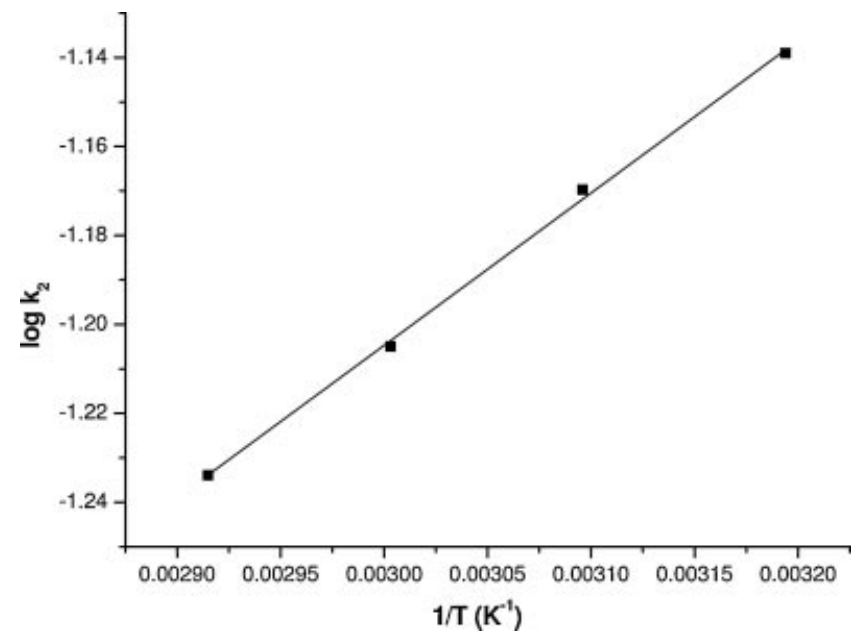

Figure 5. Plot of $\log k_{2}$ and $1 / T$.

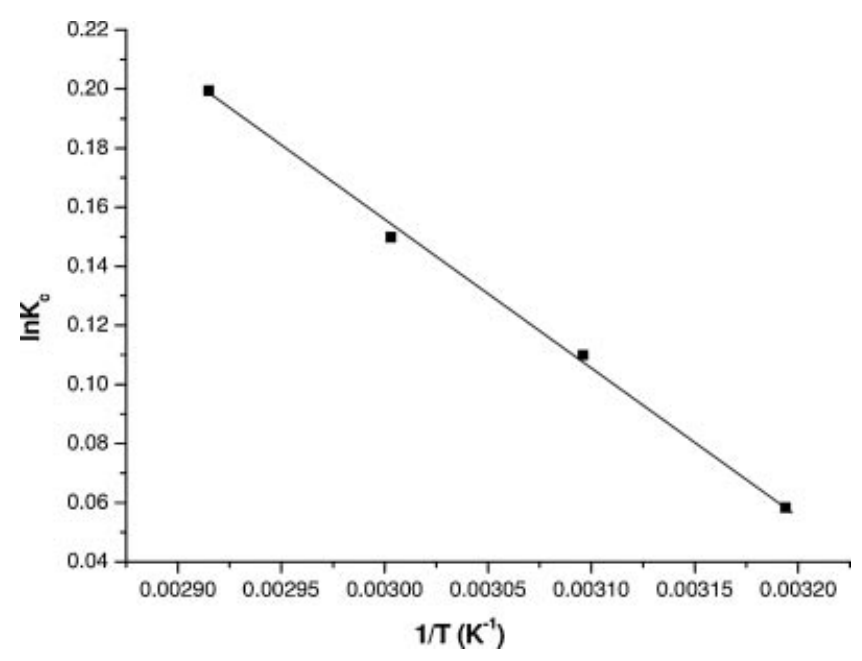

Figure 6. Plot of $\ln K_{\mathrm{c}}$ and $1 / T$.

of adsorption capacity of electrocoagulant (ferric hydroxide) at higher temperatures may be attributed to the enlargement of pore size and or activation of the adsorbent surface. Using Lagergren rate equation, first order rate constants and correlation co-efficient were calculated for different temperatures (305-343 K). The calculated ' $q_{\mathrm{e}}$ ' values obtained from the second order kinetics agrees with the experimental ' $q_{\mathrm{e}}$ ' values better than the first order kinetics model, indicating adsorption following second order kinetics. Table 5 depicts the computed results obtained from first and second order kinetic models.
Table 6. Pore diffusion coefficients for the adsorption of boron at different concentration and temperature

\begin{tabular}{lc}
$\begin{array}{l}\text { Concentration } \\
\left(\mathrm{mg} \mathrm{L}^{-1}\right)\end{array}$ & $\begin{array}{c}\text { Pore diffusion constant } \\
D \times 10^{-9}\left(\mathrm{~cm}^{2} \mathrm{~s}^{-1}\right)\end{array}$ \\
\hline 3 & 2.33 \\
4 & 1.92 \\
5 & 0.76 \\
6 & 0.64 \\
7 & 0.53 \\
\hline & Pore diffusion constant \\
Temperature (K) & $D \times 10^{-9}\left(\mathrm{~cm}^{2} \mathrm{~s}^{-1}\right)$ \\
\hline 313 & 0.66 \\
323 & 0.93 \\
333 & 1.66 \\
343 & 2.03
\end{tabular}

The diffusion co-efficient $(D)$ for intraparticle transport of boron species into the adsorbent particles has been calculated at different temperature by:

$t_{1 / 2}=0.03 \times\left(\frac{r_{o}{ }^{2}}{D}\right)$

where $t_{1 / 2}$ is the time of half adsorption (s), $r_{\mathrm{o}}$ is the radius of the adsorbent particle $(\mathrm{cm}), D$ is the diffusion co-efficient in $\mathrm{cm}^{2} \mathrm{~s}^{-1}$. For all chemisorption system, the diffusivity co-efficient should be $10^{-5}$ to $10^{-13} \mathrm{~cm}^{2} \mathrm{~s}^{-1}$ (Yang and Al-Duri, 2001). In the present work, $D$ is found to be in the range of $10^{-10} \mathrm{~cm}^{2} \mathrm{~s}^{-1}$. The pore diffusion coefficient $(D)$ values for various temperatures and different initial concentrations of boron are presented in Table 6.

\section{Process Scale-up}

On the basis of results obtained on the laboratory scale, a large capacity cell was designed, fabricated and operated for the removal of boron from drinking water. The solution of 8.5 L was used for each experiment as the electrolyte. A cell [0.35 (length $\times 0.25$ (width) $\times 0.25 \mathrm{~m}$ (height) $]$ was fitted with PVC cover having suitable holes to introduce anode, cathode, thermometer and the electrolyte acted as the cell. A mild steel anode $[0.17$ (width) $\times 0.18 \mathrm{~m}$ (height) $]$ was used. Stainless steel plates of same dimension as that of anode were used as cathode. The cell was operated at $0.2 \mathrm{~A} \cdot \mathrm{dm}^{-2}$ and the electrolyte $\mathrm{pH}$ of 7.0. The results showed that the maximum removal efficiency of $93.1 \%$ was achieved at a current density of $0.2 \mathrm{~A} . \mathrm{dm}^{-2}$ and a pH of 7 using mild steel as the anode and stainless steel as the cathode. The results were consistent with the results

Table 5. Comparison between the experimental and calculated $q_{\mathrm{e}}$ values for the boron concentration of $5 \mathrm{mg} \mathrm{L}^{-1}$ in first and second order adsorption kinetics

\begin{tabular}{|c|c|c|c|c|c|c|c|}
\hline Concentration $\left(\mathrm{mg} \mathrm{L}^{-1}\right)$ & $q_{\mathrm{e}}(\exp )$ & $q_{\mathrm{e}}(\mathrm{Cal})$ & $K_{1} \times 10^{4}\left(\mathrm{~min} \mathrm{mg}^{-1}\right)$ & $R^{2}$ & $q_{\mathrm{e}}(\mathrm{Cal})$ & $K_{2} \times 10^{4}\left(\mathrm{~min} \mathrm{mg}^{-1}\right)$ & $R^{2}$ \\
\hline 323 & 3.6632 & 28.65 & -0.0052 & 0.8134 & 3.5932 & 0.0531 & 0.9996 \\
\hline 333 & 3.8012 & 31.34 & -0.0067 & 0.8533 & 3.6221 & 0.0614 & 0.9864 \\
\hline 343 & 3.8315 & 33.34 & -0.0083 & 0.8634 & 3.9943 & 0.0648 & 0.9644 \\
\hline
\end{tabular}


a

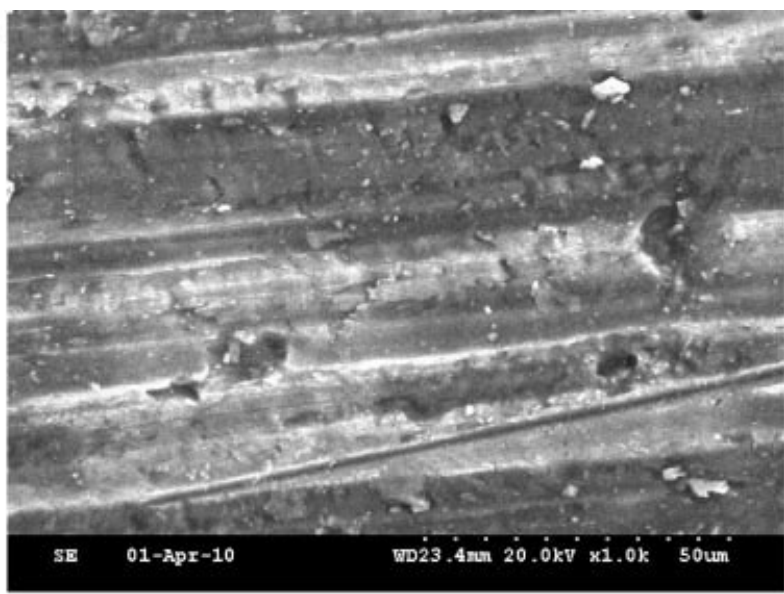

b

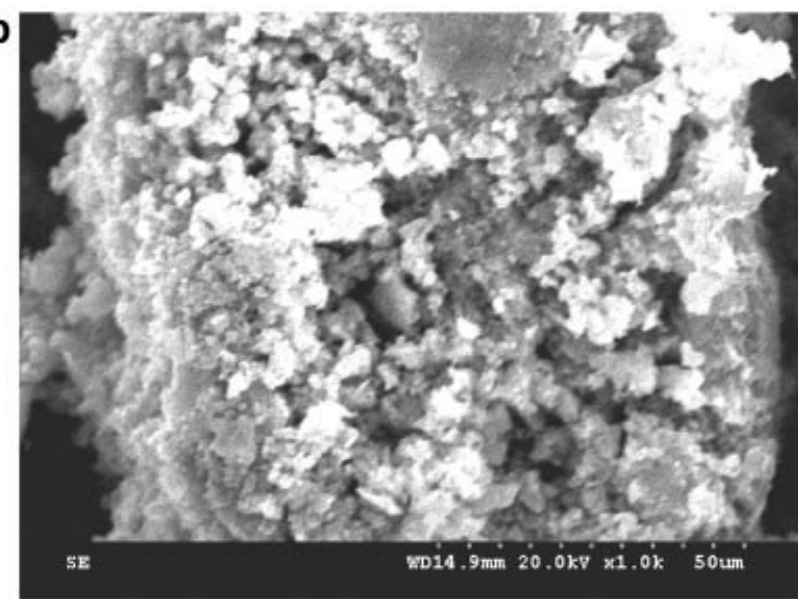

Figure 7. SEM image of the mild steel anode (a) before and (b) after treatment.

obtained from the laboratory scale, showing the robustness of the process.

\section{Material Characterisation}

\section{SEM and EDAX studies}

To gain further insight, the morphology of the electrode surface was studied by SEM/EDAX (Figures 7 and 8). SEM images of mild steel electrode, before and after, electrocoagulation of boron electrolyte was obtained to compare the surface texture. Figure 7a shows the original mild steel plate surface prior to its use in electrocoagulation experiments. The surface of the electrode is uniform. Figure $7 \mathrm{~b}$ shows the SEM of the same electrode after several cycles of use in electrocoagulation experiments. The electrode surface is now found to be rough, with a number of dents. These dents are formed around the nucleus of the active sites where the electrode dissolution results in the production of ferric hydroxides. The formation of a large number of dents may be attributed to the anode material consumption at active sites due to the generation of oxygen at its surface.

Energy-dispersive analysis of X-rays was used to analyse the elemental constituents of ferric hydroxide after boron adsorption (Figure 8). The presence of $\mathrm{B}, \mathrm{Fe}$ and $\mathrm{O}$ appears in the spectrum thus providing direct evidence that boron is adsorbed on the ferric hydroxide. Other elements detected in the ferric hydroxide come from adsorption of the conducting electrolyte, chemicals used in

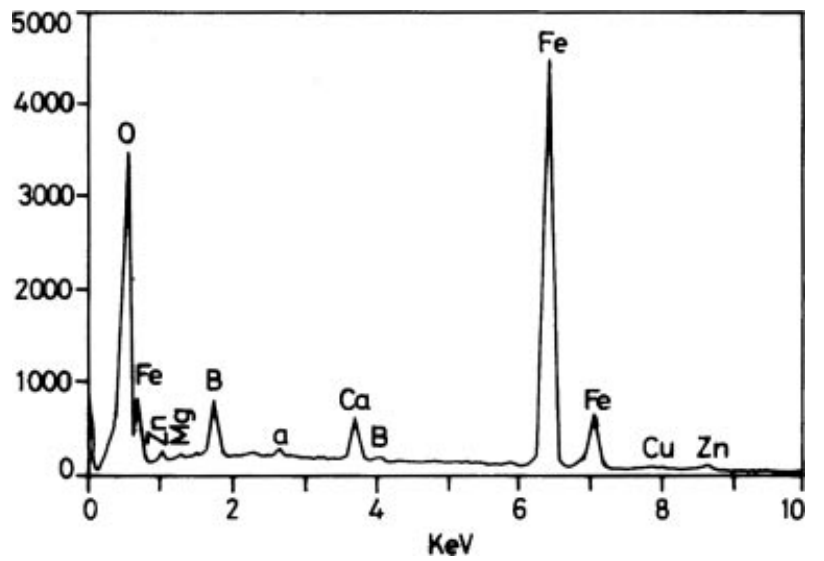

Figure 8. EDAX spectrum of boron-adsorbed ferric hydroxide.

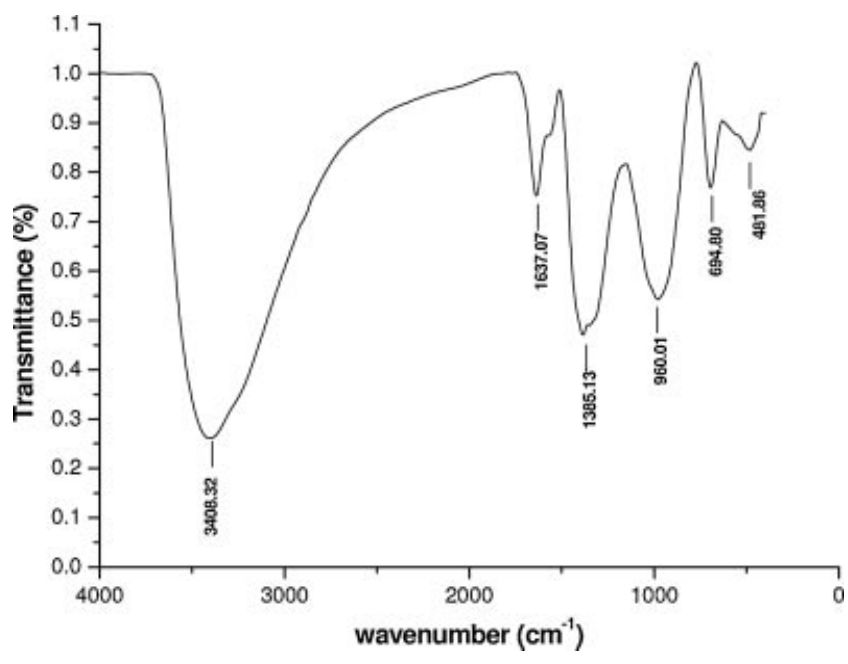

Figure 9. FTIR spectrum of boron-adsorbed ferric hydroxide.

the experiments, alloying and the scrap impurities of the anode and cathode.

\section{FTIR Studies}

Figure 9 presents the FT-IR spectrum of boron-ferric hydroxide. The sharp and strong peak at $3408.32 \mathrm{~cm}^{-1}$ is due to the $\mathrm{O}-\mathrm{H}$ stretching vibration in the $\mathrm{Fe}(\mathrm{OH})_{3}$ structures (HernandezMoreno et al., 1985). The 1637.07 and $1385.13 \mathrm{~cm}^{-1}$ peak indicates the bent vibration of $\mathrm{H}-\mathrm{O}-\mathrm{H}$. The strong peak at $960.01 \mathrm{~cm}^{-1}$ is assigned to the $\mathrm{Fe}-\mathrm{O}-\mathrm{H}$ bending. B-O vibration at $694.80 \mathrm{~cm}^{-1}$ also observed.

\section{CONCLUSIONS}

The results showed that the optimised removal efficiency of $93.2 \%$ was achieved at a current density of $0.2 \mathrm{~A} \mathrm{dm}^{-2}$ and $\mathrm{pH}$ of 7.0 using mild steel as anode and stainless steel as cathode. The ferric hydroxide generated in the cell remove the boron present in the water and made it for drinking. The results showing that the process was technologically feasible. The adsorption of boron preferably fitting the Langmuir adsorption isotherm suggests monolayer coverage of adsorbed molecules. The adsorption process follows second order kinetics. Temperature studies showed that adsorption was endothermic and spontaneous in nature. 


\section{ACKNOWLEDGEMENTS}

The authors wish to express their gratitude to the Director, Central Electrochemical Research Institute, Karaikudi to publish this article.

\section{REFERENCES}

Ali, I. and V. K. Gupta, “Advances in Water Treatment by Adsorption Technology,” Nat. Protocols 1, 2661-2667 (2007).

Allen, S. J., G. Mckay and K. H. Y. Khader, "Intraparticle Diffusion of Basic Dye During Adsorption Onto Sphagnum Peat," Environ. Pollut. 56, 39-50 (1989).

Baek, K. W., S. H. Song, S. H. Kang, Y. W. Rhee, C. S. Lee, B. J. Lee, S. Hundson and T. S. Hwang, "Adsorption Kinetics of Boron by Anion Exchange Resin in Packed Column Bed,” J. Ind. Eng. Chem. 13, 325-484 (2007).

Bick, A. and G. Ora, "Post-treatment Design of Seawater Reverse Osmosis Plants: Boron Removal Technology Selection for Potable Water Production and Environmental Control,” Desalination 178, 232-236 (2005).

Bouguerra, W., A. Mnif, B. Hamroouni and M. Dhahbi, "Boron Removal by Adsorption Onto Activated Alumina and by Reverse Osmosis," Desalination 223, 31-37 (2008).

Bryjak, M., J. Wolska and N. Kabay, "Removal of Boron From Seawater by Adsorption-Membrane Hybrid Process: Implementation and Challenges," Desalination 223, 57-62 (2008).

Chen, G., "Electrochemical Technologies in Wastewater Treatment,” Sep. Purif. Technol. 38, 11-41 (2004).

Chen, X., G. Chen and P. L. Yue, "Modeling the Electrolysis Voltage of Electrocoagulation Process Using Aluminum Electrodes,” Chem. Eng. Sci. 57, 2449-2455 (2002).

Demiral, H., I. Demiral, F. Tumsek and B. Karacbacakoglu, "Adsorption of Chromium(VI) From Aqueous Solution by Activated Carbon Derived From Olive Bagasse and Applicability of Different Adsorption Models," Chem. Eng. J. 144, 188-196 (2008).

EnnilKose, T. and N. Ozturk, "Boron Removal From Aqueous Solutions by Ion-Exchange Resin: Column Sorption-Elution Studies,” J. Hazard. Mater. 152, 744-749 (2008).

Gasser, M. S., G. H. Morad and H. F. Aly, "Batch Kinetics and Thermodynamics of Chromium Ions Removal From Waste Solutions Using Synthetic Adsorbents,” J. Hazard. Mater. 142, 118-129 (2007).

Giles, C. H., T. H. MacEwan, S. N. Nakhwa and D. Smith, "Studies in Adsorption. Part XI. A System of Classification of Solution Adsorption Isotherms, and its Use in Diagnosis of Adsorption Mechanisms and in Measurement of Specific Surface Areas of Solids,” J. Chem. Soc. 12, 3973-3993 (1960).

Golder, A. K., A. N. Samantha and S. Ray, "Removal of Phosphate From Aqueous Solutions Using Calcined Metal Hydroxides Sludge Waste Generated From

Electrocoagulation," Sep. Purif. Technol. 52, 102-109 (2006).

Guidelines for Drinking-Water Quality, WHO 2nd edn. (1998).

Gupta, V. K., I. Ali and V. K. Saini, "Removal of Fluoride From Water by Adsorption on Carbon Slurry: A Waste Material of Fertilizer Industry," Water Res. 41, 3317-3326 (2007).

Gupta, V. K., P. J. M. Carrott, M. M. L. Ribeiro Carrott and A. Suhas, "Low Cost Adsorbents: Growing Approach to Wastewater Treatment-A Review,” Crit. Rev. Environ. Sci. Technol. 39, 783-842 (2009).
Hazef, A. I., M. S. Manharawy and M. A. Khedr, "RO Membrane Removal of Unreacted Chromium From Spent Tanning Effluent. A Pilot-Scale Study," Part 2, Desalination 144, 237-242 (2002).

Hernandez-Moreno, M. J., M. A. Ulibarri, J. L. Renon and C. J. Serna, "IR Characteristics of Hydrotalcitelike Compounds," Phys. Chem. Miner. 12, 34-38 (1985).

Inglezakis, V. J., M. D. Loizidou and H. P. Grigoropoulou, "Ion Exchange of $\mathrm{Pb}^{+}, \mathrm{Cu}^{+}, \mathrm{Fe}^{+}$, and $\mathrm{Cr} 3^{+}$on Natural Clinoptilolite: Selectivity Determination and Influence of Acidity on Metal Uptake,” J. Colloid Interface Sci. 261, 49-54 (2003).

Jiang, J. G., Y. Xu, K. Quill, J. Simon and K. Shettle, "Laboratory Study of Boron Removal by Mg/Al Double-Layered Hydroxides,” Ind. Eng. Chem. Res. 46, 4577-4583 (2007).

Kabay, N., O. Arar, F. Acar, A. Ghazal, U. Yuksel and M. Yuksel, "Removal of Boron From Water by Electrodialysis: Effect of Feed Characteristics and Interfering Ions," Desalination 223, 63-69 (2008).

Kistler, R. B. and C. Helvacı, "Boron and Borates," 6th ed., Society of Mining, Metallurgy and exploration, Inc., New York, USA (1994).

Langmuir, I., "The Adsorption of Gases on Plane Surfaces of Glass, Mica and Platinum,” J. Am. Chem. Soc. 40, 1361-1403 (1918).

Mckay, G. and Y. S. Ho, "The Sorption of Lead(II) Ions on Peat," Water Res. 33, 578-584 (1999).

Michelson, P., G. Gideon, E. G. Pace and L. H. Kutal, "Office of Water Research and Technology Bulletin,” US Department of Industry, Washington, DC (1975).

Namasivayam, C. and K. Prathap, "Recycling Fe(III)/Cr(III) Hydroxide, an Industrial Solid Waste for the Removal of Phosphate From Water," J. Hazard. Mater. 123B, 127-134 (1999).

Oguz, E., "Adsorption Characteristics and Kinetics of the $\mathrm{Cr}(\mathrm{VI})$ on the Thuja Oriantalis," Colloid Surf. A 252, 121-128 (2005).

Oke, I. A., N. O. Olarinoye and S. R. A. Adewusi, "Adsorption Kinetics for Arsenic Removal From Aqueous Solutions by Untreated Powdered Eggshell," Adsorption 14, 73-83 (2008).

Peter, A., "Distribution of Boron in the Environment," Bio. Trace Element Res. 66, 131-143 (1998).

Sahin, S., "A Mathematical Relationship for the Explanation of Ion Exchange for Boron Adsorption," Desalination 143, 35-43 (2003).

Sartaj, M. and L. Fernandes, "Adsorption of Boron From Landfill Leachate by Peat and the Effect of Environmental Factors," J. Environ. Eng. Sci. 4, 19-28 (2005).

Senkal, B. K. and N. Bicak, "Polymer Supported Iminodipropylene Glycol Functions for Removal of Boron," React. Funct. Polym. 55, 27-33 (2003).

Singh, K. K., R. Rastogi and S. H. Hasan, "Removal of Cadmium From Wastewater Using Agriculture Waste Rice Polish,” J. Hazard. Mater. 121 A, 51-58 (2005).

Srivastava, V. C., I. D. Mall and I. M. Mishra, "Characterisation of Mesoporous Rice Husk Ash (RHA) and Adsorption Kinetics of Metal Ions From Aqueous Solution Onto RHA,” J. Hazard Mater. B134, 257-267 (2006).

Tan, I. A. W., B. H. Hameed and A. L. Ahmed, "Equilibrium and Kinetic Studies on Basic Dye Adsorption by Oil Palm Fibre Activated Carbon," Chem. Eng. J. 127, 111-119 (2007).

Thella, K., B. Verma, C. V. Srivastava and K. K. Srivastava, "Electrocoagulation Study for the Removal of Arsenic and 
Chromium From Aqueous Solution,” J. Environ. Sci. Health Part A 43, 554-562 (2008).

Uber, F. H., "Die Adsorption in Losungen,” Z. Phy. Chem. 57, 381-387 (1906).

Vasudevan, S., J. Lakshmi and G. Sozhan, "Studies on the Mg-Al-Zn-Alloy as Anode for the Removal of Fluoride From Drinking Water in Electrolcoagulation Process," Clean 37, 372-378 (2009a).

Vasudevan, S., J. Lakshmi and G. Sozhan, "Studies on the Removal of Iron From Drinking Water by Electrocoagulation-A Clean Process," Clean 37, 45-51 (2009b).

Vasudevan, S., J. Lakshmi, J. Jayaraj and G. Sozhan, "Remediation of Phosphate-Contaminated Water by Electrocoagualtion With Aluminium, Aluminum Alloy and Mild Steel Anodes,” J. Hazard. Mater. 164, 1480-1486 (2009c).

Vasudevan, S., J. Lakshmi and R. Vanathi, "Electrochemical Coagulation for Chromium Removal: Process Optimisation, Kinetics, Isotherm and Sludge Characterisation," Clean 38, 9-16 (2010)

Vik, E. A., D. A. Carlson, A. S. Eikum and E. T. Gjessing, "Electrocoagulation of Potable Water," Water Res. 18, 1355-1360 (1984).

Weber, W. J., Jr. and J. C. Morris, "Kinetics of Adsorption on Carbon From Solutions,” J. Sanit. Div. Am. Soc. Civ. Eng. 89, 31-60 (1963).

$\mathrm{Xu}$, Y. and J. Q. Jiang, “Technologies for Boron Removal,” Ind. Eng. Chem. Res. 47, 16-24 (2008).

Yang, X. Y. and B. Al-Duri, “Application of Branched Pore Diffusion Model in the Adsorption of Reactive Dyes on Activated Carbon," Chem. Eng. J. 83, 15-23 (2001).

Yilmaz, E. A., R. Boncukcuoglu and M. Muhtar Kocakerim, “An Empirical Model for Parameters Affecting Energy Consumption in Boron Removal From Boron-Containing Wastewaters by Electrocoagulation,” J. Hazard. Mater. 144, 101-107 (2007).

Yilmaz, E. A., R. Boncukcuoglu, M. Muhtar Kocakerim, M. Tolga Yilmaz and C. Paluluoglu, "Boron Removal From Geothermal Waters by Electrocoagulation,” J. Hazard. Mater. 153, 146-151 (2008).

Yurdakoc, M., Y. Seki, S. Karahan and K. Yurdakoc, "Kinetic and Thermodynamic Studies of Boron Removal by Siral 5, Siral 40, and Siral 80," J. Colloid Interface Sci. 286, 440-446 (2005).

Manuscript received December 31, 2010; revised manuscript received February 16, 2011; accepted for publication March 10, 2011. 